with or in any way impair the operation of this ordinance are hereby repealed, and all provisions of law and ordinances relating to the Department of Health, the Commissioner of Health, the City Physician, the inspection of food, milk, ice and drugs, and miscellaneous ordinances relating to health, shall, so far as they may be applicable, remain of full force and effect.

I will now take the bill up by sections for the purpose of explanation. Sections 1, 2 and 3 are, in my opinion, necessary to secure the perfect working of the officers and employes of the department. Indeed it will be found impossible to secure the appointment of proper persons unless the tenure of office be made more secure than has been the case under previous ordinances. Moreover, it is such as to bring the department in line with the civil service laws of the State and of the United States. I had charge of a Bureau of the Treasury Department when the present civil service law was enacted, and I am entirely familiar with its operations. Some passages in this ordinance will be recognized as quoted directly from that law.

Sections 4, 5, 6 and 7 are self-explanatory, and relate to the different classes of officers, and especially to the qualifications and appointments of the Sanitary Director and Assistant Sanitary Director.

Section 8 , relating to the City Physician, after giving the qualifications, makes specific mention of his duties.

Section 10, providing for a Sanitary Captain, is self-explanatory. It must be obvious that some one must be had to account for the property owned by the Department, to have charge of the same, and to superintend and to direct the outdoor work. This section is not only calculated to protect the interests of the city, but to prevent misuse or misapplication of any property or appliance belonging to the Department.

Sections 11 and 12 relate to the appointment of a City Chemist and a Medical Inspector, which are self-explanatory, except that definite qualifications are provided for. The system of examination of medical inspectors, as preliminary to appointment, as proposed in this ordinance, should by all means be adopted at the earliest possible moment, as the appointment of persons through motives of friendship or political association fails to secure that standard of professional qualification that a great city should always be able to command.

The adoption of an ordinance or law like this provides the skeleton organization; as will be seen, it provides for indefinite expansion by increasing the number of persons employed, when the necessity for so doing may arise; it provides for extraordinary powers in case of epidemic; and more than all, a unity of system is provided and responsibility fixed.

As all cities have an Engineer Department, City Engineer or Department of Public Works, it is not deemed necessary to provide specifically for that coöperation which may be always secured by the comity necessarily existing between different departments of the same administration. Should that fail the Mayor as chief executive can always settle the matter by special order.

The details of executive work, the regulations governing the special office and the Department, are by this organic act left to be framed by the Sanitary Director to suit the particular city. But in no case need they conflict with the organic law, which, as will be seen, is sufficiently broad to allow the framing of all necessary regulations.
NoTE. - The essential features of this draft were commented upon with approval by the distinguished editor of the Joum al d'Hygiène of Paris, and a translation formally presented to the Société d'Hygiène.

THE METHODS OF DRAINAGE NOW PREVAILING IN SOME OF OUR EASTERN SEABOARD MUNICIPALTTIES, TEND. ING TO THE PRODUCTION AND DISSEMINATION OF DISEASE.

Read in the Section on State Medicine, at the Forty-seventh Annual Meeting of the American Medical Association, held at
Atlanta, Ga.. Niay 5-8. 1896 .

BY AUGUSTUS P. CLARKE, A.M., M.D. CAMBLIDGE. MASS.

Crudely constructed latrines and cesspools, without connections with regularly laid drains, were the devices which often obtained among the early inhab. itants of the country; they were places for receiving the waste water and the dejecta of occupants of houses and other buildings, and were for the most. part recommended merely for the convenience they afforded. The method which these contrivances furnished for disposing of refuse liquids and excrementitions elements worked no serious manifest injury unless some of the more deleterious products had gained, by percolating through the surrounding soil, admission into a well or other source of water to be used for domestic purposes. Among the more dangerous products of this class have been those derived from the albuminoids and the nitrates, and from carriers of some of the forms of bacteria that were capable of giving rise to diseases that have been regarded as of a zymotic character. The development of morbid conditions from such sources in sparsely inhabited districts has not been of common occurrence, from the fact that the free ventilation which takes place through the open vaults, and also the diluting action of water from the frequent storms, have had a counteracting effect upon the potency of the bacterial agents, and have thus rendered immunity to persons not particularly susceptible to influences of such disease factors.

As these places became more densely populated, there were also built, in connection with the receptacles, different forms of drains, into which the fluid and the less solid portions of the waste matter were discharged. Beyond this measure of dealing no very definite plan at first for the disposing of sewage was maintained, and so the contents of the drain were disembogued into a stream or water-course that perchance could be found in the vicinity. When the discharge was made into rivers whose courses had a steep and rapid descent, very little seemingly ill effects were experienced by those who dwelt above the point of the inlet. Those who dwelt along the river banks or in the valleys below were not always so fortunate, especially when they found it necessary to take from the river in that vicinity their water supply. Water of large streams, if charged with deleterious products, will not after flowing several miles become wholly innocuous and be safe for drinking purposes. The tenacity of life possessed by certain bacterial elements will not be overcome by such an inadequate exposure. In this connection it is but just to remark that it is not so much the negative testimony of the chemist and the microscopist that insures safety in the choice of the drinking water, as it is that there exist no possible sources of contamination. 
Many of our larger cities have already inaugurated measures for taking water where the unhealthful influences have been reduced to the minimum. Unfortunately, however, this freedom from contamination does not prevail in the majority of municipalities. Among the more prominent objectionable features of the present methods of drainage for municipalities is that of discharging large quantities of refuse matter into sewers which are connected, either directly or indirectly, with rivers that receive tide-water. The people dwelling in the less densely populated portions of a city or town where a good-sized sewer has its outlet into the river through a gate that opens and closes with the ebb and flow of the tide may not, perhaps, suffer to any great extent in availing themselves of the use of such a drain. A long open drain, however, connecting at one end with residences and at the other with tide gates to allow its vile contents to be discharged so as to be exposed to the rays of a summer's sun, and to have its evaporations wafted back through the long conduit by the counter-currents of air set up, and drawn back to the homes of the occupants, presents features that are far from being conducive to health.

A still more dangerous factor results even after the closure of the gates from the oncoming tide, by the rapid filling up of the sewer from the numberless drain pipes that are directly connected with the government drain; this arrangement tends to displace the air laden with poison or pathogenic organisms, and force it back toward the house connections with the sewer. When the pressure that produces this reflux is moderate, the effect may be overcome by the water in the closet traps, but during the time when there is much storm water to be carried off the pressure becomes inordinate, and thus forces not only the mephitic air, but causes a reflux of the filthy water; this may pass through the traps that are lower down, and in some instances also through those placed as high as the street level. This has been particularly noticed when great storms have been raging. The numerous conductors extending from the many high buildings in the neighborhood to these sewers tend to force, in accordance with a well-known law in physics, the water up through the house drains above the normal level, and thus to flood the basements and cellars with water and sewage that have been collecting in the drain during the storms and while the tide gates were closed.

This unhealthful condition of things has gradually increased since the custom of building large apartment houses and of other high structures has obtained. To show the inadequacy of the sewers or the drain traps employed for preventing the reflux when the sewer is being filled by the accumulation of storm water flowing from the conductors of high buildings and from the street catch basins during the closure of a tide gate, a drain pipe connected with a sewer lead. ing to a house whose basement had been flooded by a regurgitation of storm water through the bowls, on being opened to determine its condition, a jet of water like a geyser spouted up several feet into the air, and continued thus to flow until the drains had been relieved of their excessive pressure.

The objectionable features arising from such a defective method of drainage have been sought to be overcome by the construction, at an enormous expense, of what has been designated as the "metropolitan sewer," for the accommodation of the inhab- itants of Boston and of other municipalities within a certain radius. The benefits to be derived by the laying of this drain are not altogether what was generally anticipated, for the reason that the sewer is not of sufficient capacity for receiving and carrying off in a proper manner the storm water, in addition to the sewage it has to take in. The sewer has been built out some distance into Boston harbor, where the contents are discharged by means of large pumps into the deep water, that they may be borne out with the tide into the sea.

The object of the expedients adopted or suggested by the engineers of the cities that have been interested in the construction of the work, is that the storm water entering the great sewer may by an automatio device escape into the local sewers, and so pass into the Charles River or other water-courses with which they may be connected. It requires but little reflection for any one to comprehend the fact that more or less actual sewage will still be carried along with the storm waters into the river, and that the cessation of contamination of our natural water-courses by the carrying into them of drainage material will only be accomplished theoretically and not in real practice. Again, the storm water can be discharged by the devices above mentioned from the local sewers into the rivers only at ebb tide and while the gates are open. At other times the entering waters coming from the heavy rains will not all pass on, and when the sewers become overcharged will take a backward flow into the estates embraced within the lower sections of the district, as has so often occurred by the operation of the old system of drainage, with this difference, perhaps, that the new method, as the sections become more crowded, will nevertheless give rise to a greater reflux of the sewer contents.

It should be stated that some twenty years ago or more, statutes by the State government were passed, requiring certain lands below thirteen feet above mean low water mark to be raised to grade. The difficulties that are now being experienced are not, however, con. fined to such districts that have been filled, but are met with to some extent in places that are of a higher grade. It is too bad that after the, enormous outlay of money that has been made by the inhabitants, and the annoyances and vexations experienced, beside the expenditure for the construction of sewers, so little of real permanent value has been achieved. This result is not dissimilar to the experiences of other State governments when they have attempted to accomplish any great, new and lasting benefit.

In order to overcome the unhealthful features incident to the working of the present system of drainage special sewers for carrying off the storm water should be laid. Into these should pass all the water from roofs, gutters or conductors upon buildings, and the storm water of the streets after it has been well filtered through catch basins to deprive it of its more solid portions. These water conduits should be laid so deep that the water in the cellar and foundation wall trenches for some inches below the deepest portion of a cellar bottom may readily flow into them, to be carried off to the rivers or other depths of natural water channels.

In cases of tidal rivers there should be for the most part no tide gates; deep basins should be constructed for receiving such waters, that, after being filtered, could be discharged, by means of a pumping station, into the river. For times of great drought these 
waters could be stored in receiving basins and could be ased for the extinguishing of fires and for other purposes in cases of emergency.

The State Board of Health has already recom. mended that some independent system of sewerage should be employed for the disposition of storm waters. For one particular part of our city our mayor has given some encouragement that he would manifest his official influence for the construction of a sewer for the greater relief of water coming during the heavy storms. No definite experiments as yet have been instituted for determining the feasibility of carrying out the plan here proposed, but it is evident that something more radical than what has heretofore been attempted will have to be undertaken for the insuring of permanent relief and healthfulness in our municipalities.

Until there are adopted plans for drainage founded on more scientific principles than those still prevailing, we can not expect to achieve any great results in diminishing the occurrence of many forms of disease. We may raise the standard of our medical colleges and our universities, may improve our methods in pharmacy, extend the list of articles and remedial agents in our materia medica, and develop to the highest degree our surgical technique, but these promising helps will still be found capable of relieving only a mere moiety of the sum total of the suffering from disease, so long as occupants of dwellings continue to be exposed to the increasing dangers of overcrowding that is everywhere now taking place.

\section{A DEPARTMENT OF HEALTH, OR A BUREAU: WHICH?}

Read in the Section on State Medicine, at the Forty-seventh Annual Meeting of the American Medical Association at Atlanta, Georgia, May 5-s, 1896.

BY S. S. HERRICK, M.D.

$$
\text { SAN FRANCISCO. }
$$

It is assumed that the American Medical AssociaTION substantially agree that the time has come for some permanent branch of our national government to promote and administer the interests of public health. There is, however, a variety of plans of organization, each of which has its merits and defects. the most prominent of which may be designated a board of health, a department, a bureau, and the continuance of the present method as administered by the Marine-Hospital Service.

The plan of a board of health has been tried, with such want of success that, in my opinion, it would be unwise to experiment again. It is needless now to consider where the fault chiefly lay; and there are too many yet living and active, who participated in the controversy, safely to risk the danger of its revival. The plan most favored by the AMERICAN Medical Association has been to create a department of public health, presided over by a secretary holding a seat in the President's Cabinet. Its conspicuous aim is to magnify the importance of public health and extract a large appropriation from the treasury. Without detracting from the value of health as one of the enjoyments of life, we must not overlook the fact that other great interests are clamoring for recognition and an appropriation. The agriculturists, who now number approximately 9,000,000 of our population, have recently secured a separate department. It may be expected that those engaged in manufacturing and mining (about 5,000,000) will soon demand like consideration, and that they will be followed in due time by the trade and transportation interest (numbering about 2,500,000). The two latter are already anticipated by the sanitary interest, which may be represented by about 100,000 . Roughly speaking, this number is now classed in the medical ranks (regular, irregular and defective), and I think it would be fair to deduct, as not being interested in sanitation, quite as many as should be added to those so interested from the laity. Teachers and scientists (representing the educational interest) now number approximately 300,000 , or three times as many as the sanitarians. In 1867, the Bureau of Education was created by act of Congress, and it has done excellent work ever since. So far as I have learned, both the public and educators are satisfied with their modest organization, though, doubtless, they would like more money.

In 1885 the present writer, recognizing the excellent work done by the Bureau of Education, being deeply impressed with the need of a national sanitary service and at the same time warned by the troubles which had befallen the National Board of Health, formulated a plan for a bureau of health, which was approved by the American Public Health Association. Under its auspices a bill for this purpose was framed and introduced in Congress. It would serve no useful purpose here to dwell upon the reasons of its failure. In substance the proposed functions of the bureau were the following:

1. To gather information upon the state of the public health and the existence of contagious disease in foreign countries through the consulates of the United States government; to digest and communicate the same to all government posts and health authorities of our country; through medical officers attached to the consulates, when requested by the masters of vessels destined for ports of the United States, to inspect the vessels, cargoes, crews and passengers (including their personal effects), to use measures for cleansing and disinfection, and to vaccinate those requiring vaccination (all at the expense of the vessel), to furnish bills of health relative to the port of departure and full dealing with the vessel, or to notify the bureau by telegraph of neglect or refusal to accept such service.

2. To serve as a medium of intelligence in sanitary matters, including vital statistics, between health authorities throughout the United States, by means of a weekly publication, which would contain also foreign intelligence.

3. To inspect the various quarantine stations of the United States from time to time; to investigate outbreaks of pestilential disease in any part of the Union; to report such inspections and investigations; to recommend to local health authorities needed preventive and suppressive measures.

4. To conduct chemic, physiologic and pathologic investigations in the interest of sanitation.

5. To publish and distribute documents relative to public health.

It was contemplated to authorize the bureau to require the detail of suitable medical officers from the Army, Navy and Marine-Hospital Service for carrying out its functions at home and abroad. This would be a measure of economy and also a safeguard against political intermeddling. At that time it was not thought wise to give the bureau powers in quarantine matters, but it is now probable that there 